\title{
Green, Blue and Grey Bioenergy Water Footprints, a Comparison of Feedstocks for Bioenergy Supply in 2040
}

\author{
P. W. Gerbens-Leenes ${ }^{1}$
}

Received: 28 November 2017 / Accepted: 25 May 2018 / Published online: 7 June 2018

(C) The Author(s) 2018

\begin{abstract}
Today, traditional biomass contributes $75 \%$ to total bioenergy use, but the share of modern biomass, e.g., for biofuels or electricity, increases. Bioenergy derives from first (food crops), second (energy crops or agricultural residues) and third (algae) generation feedstocks. There is an ongoing debate about the competition between energy and food crops. Energy crops do not compete with food directly, but indirectly, using the same natural resources like freshwater. Instead of food or energy crops, crop residues can also be used for bioenergy supply. This paper uses the water footprint (WF) concept and compares WFs of first, second and third generation bioenergy $\left(\mathrm{m}^{3} / \mathrm{GJ}\right)$. Next, it compares WFs of future bioenergy demand based on different bioenergy feedstocks. WFs of energy from residues is smallest, WFs of energy crops largest. Bioenergy from algae has the largest blue WF (surface and groundwater). From a resource-use perspective, environmental impacts of green WFs (precipitation) are smaller than impacts of blue WFs. If bioenergy production rises, impacts on freshwater also go up. Increased production of first generation biofuels and energy crops contributes to global water scarcity. Third generation bioenergy, substantially increases the global blue WF. Comparing feedstocks in the IEA 450 scenario shows that all feedstocks, except residues, generate WFs larger than the global WF over the period 1996-2005. Technology to convert residues into bioenergy is developing, e.g., thermochemical or biochemical conversions. There is large potential for residues, but new possibilities to convert residues into bioenergy need to be explored, combined with possible residue use elsewhere.
\end{abstract}

Keywords Water footprint · Bioenergy · First, second and third generation biofeedstocks

P. W. Gerbens-Leenes

p.w.leenes@rug.nl

1 Center for Energy and Environmental Studies, Faculty of Science and Engineering, University of Groningen, Nijenborg 6, 9747 AGGroningen, The Netherlands 


\section{Introduction}

To decrease carbon dioxide emissions, biomass feedstocks for bioenergy seem a good alternative to replace fossil fuels. In 2014, the world energy demand was 574 EJ of which biomass provided $59 \mathrm{EJ}$ and other renewables, i.e., hydropower, wind, geothermal and solar energy, another 21 EJ (IEA 2016). With a contribution of 10\% to total energy demand in 2014, biomass provided the largest share of all renewables. The two categories of biomass for energy are traditional biomass and modern biomass. Traditional biomass comprises wood, charcoal, crop residues and animal dung, and is mainly used for heating purposes (IEA 2012). Traditional biomass is applied in various ways, mainly in developing countries, primarily for cooking and heating. Traditional biomass has many disadvantages. Often, women burn the biomass in open fires and small stoves with very low efficiencies, generating smoke that might cause health problems, while wood gathering causes overexploitation of forests (Fritsche and Iriartre 2014). Modern biomass for energy includes food crops, energy crops, crop residues, or algae, for example. The supply of traditional biomass to the total bioenergy supply is around 75\% and modern biomass contributes another 25\% (Fritsche and Iriartre 2014). Energy scenarios indicate a larger contribution of bioenergy to the total energy supply in the future (IEA 2016). Modern biomass will probably increase its share of the bioenergy supply. Modern biomass is produced in agricultural systems, including forestry, and requires freshwater for the growth of crops, trees and algae.

Freshwater is a scarce resource, because most of the world's water is saltwater and only $2.6 \%$ is freshwater, of which the largest part is stored in ice (Speidel et al. 1988). Agriculture, industry and domestic supply, with different quality standards for freshwater, are the main users. In 2000, agriculture accounted for $70 \%$ of total water withdrawals, industry for $20 \%$ and domestic withdrawals for $10 \%$ (Shiklomanov 2000). Humans influence surface water distribution, for example by building hydropower dams (Pekel et al. 2016), water storage for irrigation in agriculture, or flood control. The impacts of agriculture on freshwater availability are very large, because that sector uses the largest amounts of freshwater.

Freshwater is an important resource to generate energy, for example to cool power plants, but especially to produce bioenergy carriers that need freshwater in the agricultural stage (Gerbens-Leenes et al. 2009; IEA 2012). Several studies have investigated the relationship between energy supply and water consumption. Davies et al. (2013) made an integrated assessment of global and regional water demands for electricity generation in 2095. They showed the large water consumption of the electricity sector for cooling purposes. In 2005, water consumption for global electricity generation (without hydropower) was between 18 and $36 \mathrm{Gm}^{3}$, and rising with increased electricity generation to 40 to $100 \mathrm{Gm}^{3}$ in 2040 . Hejazi et al. (2014) have made an inventory of water consumption for different sectors in 2005 and an analysis of water consumption for different scenarios towards 2050 and 2095. They showed that in 2005 water consumption for electricity generation was $76 \mathrm{Gm}^{3}$, rising to 117 to 161 $\mathrm{Gm}^{3}$ in 2050. Agricultural water consumption in 2005 (blue water) was $1023 \mathrm{Gm}^{3}$ and increased to 1920 to $2584 \mathrm{Gm}^{3}$ in 2050 . In their analysis, though, Hejazi et al. (2014) did not distinguish between freshwater for food crops and energy crops and did not include water consumption related to residue use. The International Energy Agency (IEA) World Energy Outlook 2016 (IEA 2016) indicates the importance of freshwater for energy supply. It shows that between 2014 and 2040 water consumption for energy will increase from $48 \mathrm{Gm}^{3}$ to over $75 \mathrm{Gm}^{3}$ mainly due to a larger use of biofuels. Other studies calculated the specific water footprints (WFs) of bioenergy carriers. Gerbens-Leenes et al. (2014) calculated the WFs of 
bioenergy from algae. Mathioudakis et al. (2017) calculated the WFs of second generation bioenergy $\left(\mathrm{m}^{3} / \mathrm{GJ}\right)$ indicating the large differences among bioenergy carriers. The 2016 World Energy Outlook energy scenarios show an increase of total energy use, in combination with an increase of the share of renewables, especially of bioenergy (IEA 2016). The IEA has developed three different energy scenarios for 2040 with different energy mixes, all indicating an increase of total energy demand (IEA 2016). These scenarios are the 'Current policies scenario' (annual bioenergy use $77 \mathrm{EJ}$ ), the 'New policies scenario' (annual bioenergy use $79 \mathrm{EJ}$ ) and the '450 scenario' (annual bioenergy use $97 \mathrm{EJ}$ ). Bioenergy that derives from biomass needs large amounts of water in agriculture and forestry. Mekonnen et al. (2016) have estimated the consumptive water footprint (WF) of electricity and heat based on the four scenarios of the IEA, showing that the scenario including the largest share of bioenergy also has the largest WF due to the application of firewood and hydropower with large WFs per unit of energy.

A tool to quantify the amounts of freshwater needed for the production of goods and services, to calculate direct and indirect freshwater consumption and to assess the impact on water scarcity is the water footprint (WF) concept (Hoekstra et al. 2011). The tool is an indicator of freshwater use and defines direct and indirect water use along product supply chains. The WF is a multi-dimensional indicator, giving water consumption volumes by source and polluted volumes by type of pollution. The tool distinguishes between green, blue and grey water and in this way gives a comprehensive and complete overview of freshwater use and pollution. The green WF refers to the rainwater consumed, the blue WF refers to surface and groundwater volumes consumed (evaporated or incorporated into the product) as a result of the production of a good. The grey WF of a product refers to the volume of freshwater required to assimilate the load of pollutants based on existing ambient water quality standards (Hoekstra et al. 2011). In general, a specific focus on the blue and grey WFs is warranted, because for blue water, i.e., groundwater and surface water, water needs in agriculture compete with other human freshwater needs, like freshwater needs of municipalities (e.g., household water use) and industry.

Biomass forms the basis for the production of bioenergy carriers. For example, for transportation, the biofuels bioethanol or biodiesel are used. Biomass can also be used in a power plant to generate electricity and heat, or only heat when burned in a stove. Bioenergy includes the so-called first, second and third generation bioenergy (Gerbens-Leenes et al. 2014). First generation bioenergy is bioenergy produced from food crops. However, when crops are used to produce energy, the crops can no longer be applied for food purposes and a competition takes place. Second generation bioenergy uses energy crops or agricultural residues as a feedstock. Energy crops produced for bioenergy do not compete directly with food, but indirectly over natural resource inputs, like freshwater. Crop residues are agricultural leftovers, for example stems that are not edible, that might be an alternative for feed or energy crops. Third generation bioenergy is defined here as bioenergy from algae. The studies into the water consumption of future electricity supply (Davies et al. 2013; Hejazi et al. 2014; IEA 2016; Mekonnen et al. 2016) showed the large freshwater consumption increase that can be expected in the coming decades, is due to, among other things, larger bioenergy shares. Those studies did not make a distinction among different types of bioenergy, however. GerbensLeenes et al. (2014) assessed the specific WF of algae and made an analysis of a scenario in which EU road transport would use biofuel from algae. The pressure on water resources would go up. Mathioudakis et al. (2017) have given an overview of the WF of different energy carriers with a focus on energy carriers from residues and energy crops, showing the large differences in WFs per unit of energy. 
The aim of this paper is to present an overview of water footprints (WFs) of first, second and third generation bioenergy $\left(\mathrm{m}^{3}\right.$ per GJ) from earlier studies and to show the consequences of a large scale introduction of different types of modern bioenergy in the global energy system on water resources for 2040. The main research questions are:

- What is the average global consumptive (green, blue and grey) WF of first, second and third generation bioenergy types per unit of energy?

- What is the consumptive WF of the IEA 450 scenario for 2040 using first, second and third generation bioenergy types?

The next section, Section 2 gives background information on biomass and technologies to convert biomass into bioenergy. Section 3 shows the method and data sources applied in this study. Section 4 gives the main results. Section 5 provides a discussion on the limitations of the study. Finally, Section 6 concludes the main findings. This paper is based on earlier research into the WFs of first, second and third generation bioenergy (Gerbens-Leenes 2017). It compares WFs of different feedstocks from these earlier studies and the consequences for water if these feedstocks are to be applied on a global scale in the near future.

\section{Biomass and Conversion Technologies}

Biomass shows different categories of organic, non-fossilized materials, including not only products from agriculture and forestry, e.g., crops and wood, agricultural and forestry residues, and organic byproducts, such as manure, microbial biomass, but also industrial and household organic waste (FAO 2006). The main biomass applications are food (e.g., wheat and rice), materials (e.g., cotton and wood), fertilization (e.g., manure and crop residues), and energy (e.g., sugarcane and miscanthus). Energy crops are defined as crops grown specifically for producing energy (Cleveland and Morris 2005). The crops are annual and perennial species cultivated to produce solid, gaseous or liquid energy feedstocks (El Bassam 2010). Examples of energy crop categories are: (i) sugar-producing crops, e.g., sugar beet, sugarcane and sweet sorghum; (ii) crops rich in starch, e.g., barley, cassava, maize, potato and rye; (iii) vegetable oil-containing crops, e.g., palm oil, rapeseed, soy, sunflower and jatropha; (iv) fast-growing reed and grass plants (sometimes called 'energy crops'), e.g., miscanthus; and (v) short rotation wood, e.g., poplar, eucalyptus and willow (Cleveland and Morris 2005; De Jong and van Ommen 2014).

Farmers grow crops to produce an economic yield. They grow cereals to produce grains and potatoes to produce tubers. They grow vegetables for their leaves or stems. The growth of these organs though, requires the preceding growth of complete plants with stems and foliage. The difference between the total biomass production and the economic yield is the crop residue (rest fraction). In general, crop yields generate products, byproducts and residues. Bioenergy produced from the crop yield of food crops is called first generation bioenergy (Fischer et al. 2009). For example, maize is the feedstock for bioethanol. The rest fraction is non-edible biomass, often lignocellulosic biomass such as woody or fibrous biomass composed of cellulose, hemicellulose and lignin. These components can be transformed into more simple organic molecules (Mood et al. 2013). If the residues are used for bioenergy, the energy is called second generation bioenergy (Mood et al. 2013). For example, when sugar cane is grown, the yield, the cane, can be applied for food or used as feedstock for the production of 
first-generation biofuel. Cane molasses and bagasse, byproducts of sugar cane processing, can be used to produce second-generation bioenergy. In general, crop residues are a bulky material that cannot easily be transported globally (Ekşioğlu et al. 2010). Crop residues are also applied in agriculture to improve soil quality, so that not all crop residues are available for bioenergy (Karlen et al. 1994; Kumar and Goh 1999). When crop residues are applied for energy purposes, they gain added economic value (Gallagher et al. 2003; Koopmans and Koppejan 1997).

Fig. 1 shows the energy conversion pathways of second generation biomass into second generation bio-energy (source: Mathioudakis et al. 2017). There are two main conversion pathways for biomass: thermochemical and biochemical conversion. Thermochemical conversion includes: (i) combustion, (ii) torrefaction, (iii) gasification, and (iv) pyrolysis. Biochemical conversion includes fermentation. Biomass combustion is the chemical reaction of biomass and oxygen, giving bioenergy and oxidation products (Stevens and Brown 2011). Combustion is an exothermic process converting chemical energy to heat (Abuelnuor et al. 2014). Torrefaction is a thermochemical biomass conversion process in which biomass is slowly heated at temperatures of 200 to $300{ }^{\circ} \mathrm{C}$ in an inert or limited oxygen environment, resulting in the degradation of hemicellulose, while maximizing mass and bioenergy yield (Basu 2013). Torrefied biomass for energy purposes shows the characteristics of raw biomass and charcoal (Chen 2015).

Pyrolysis is the thermochemical conversion of biomass in a low oxygen environment at temperatures between 300 and $400{ }^{\circ} \mathrm{C}$. The conversion decomposes the biomass and generates heat, volatile gases, pyrolysis oil and solid carbon (Basu 2013). Pyrolysis oil has a relatively large oxygen content, larger than straight vegetable oil extracted from an oilseed crop like palm oil. The energy content of pyrolysis oil is smaller than the energy content of first generation oils (IEA 2007). Gasification is the thermochemical conversion of biomass to a gaseous product with a usable heating value, generating synthesis gas, syngas, consisting of hydrogen and carbon monoxide (Higman and Van der Burgt 2011). Gasification occurs at temperatures above $700{ }^{\circ} \mathrm{C}$ (Hansen 2006). All bioenergy feedstocks mentioned above can be applied to generate electricity. In that case, a power generator needs to be combined with any of the previously mentioned conversion pathways.

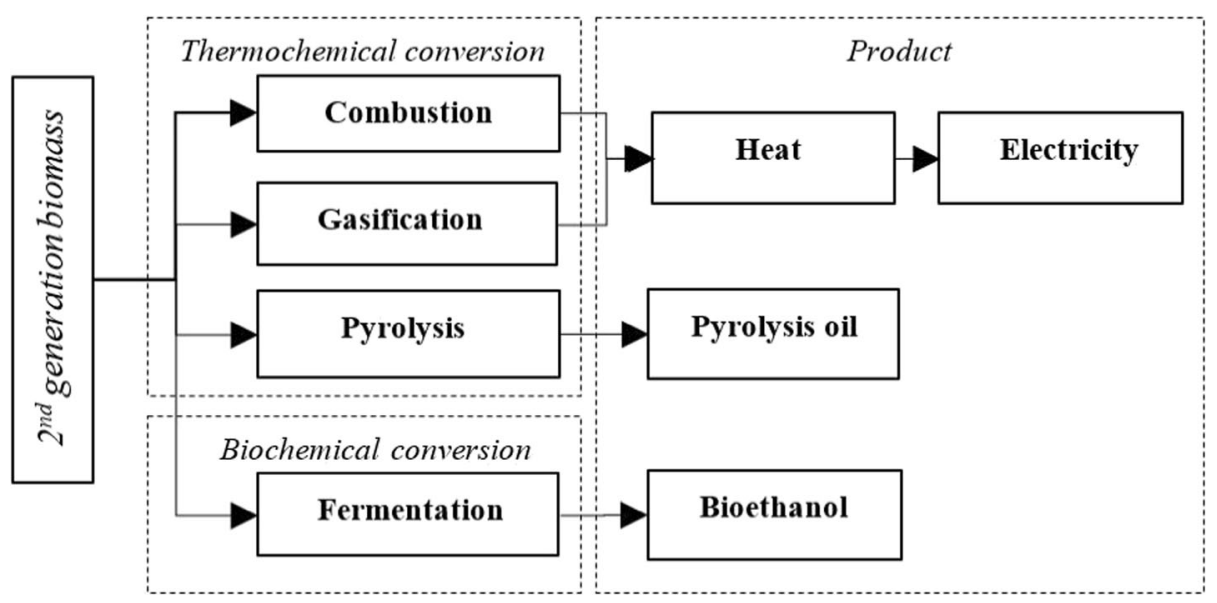

Fig. 1 Energy conversion pathways of second generation biomass into second generation bio-energy (source: Mathioudakis et al. 2017) 
In the process of biochemical conversion, bacteria or enzymes break down biomass molecules into smaller molecules that are easier to apply for bioenergy (Basu 2013). Examples are fermentation and anaerobic digestion. Fermentation converts biomass into sugars, using acids or enzymes, and ferments the biomass using yeasts to produce bio-ethanol (Basu 2013). In anaerobic digestion, biomass is degraded naturally under the absence of oxygen to biogas (Sawatdeenarunat et al. 2015).

When energy carriers are converted into other energy carriers, losses occur. Energy conversion efficiency shows how efficient one energy carrier is converted into another, and is defined as the energy output over the energy input (IEA 2008). Examples of energy efficiencies are: sugar cane combustion (0.611) (Mbohwa 2006); corn stover gasification (0.85) (Carpenter et al. 2010); and soybean straw combustion (0.73) (Repic et al. 2010).

\section{Method and Data}

Globally, there are only six crops relevant for biofuel production. These crops are sugar cane, maize, cassava, oil palm, rape and soybean (Fischer et al. 2009). Together, these crops use 22\% of the globally available arable land area or 338 million hectares of agricultural land. Only a small part of these crops, grown on $1.6 \%$ of the total cultivated land area, is applied for biofuels. Figure 2 shows the production chain of bioenergy. The biomass that forms the input for bioenergy includes food crops, residues from food crops, wood and other crops grown for energy purposes, such as miscanthus. Food crops, such as sugar cane, generate the so-called first generation bioenergy. The residues of food crops are the input for the so-called second generation bioenergy. The energy crops also generate second generation bioenergy. Algae form the input for third generation bioenergy. Bioenergy not only includes biofuels such as ethanol and biodiesel but also electricity and heat.

For the overview of the WF of first, second and third generation bioenergy types, the study derived global average data on WFs of first generation biofuels from Mekonnen and Hoekstra

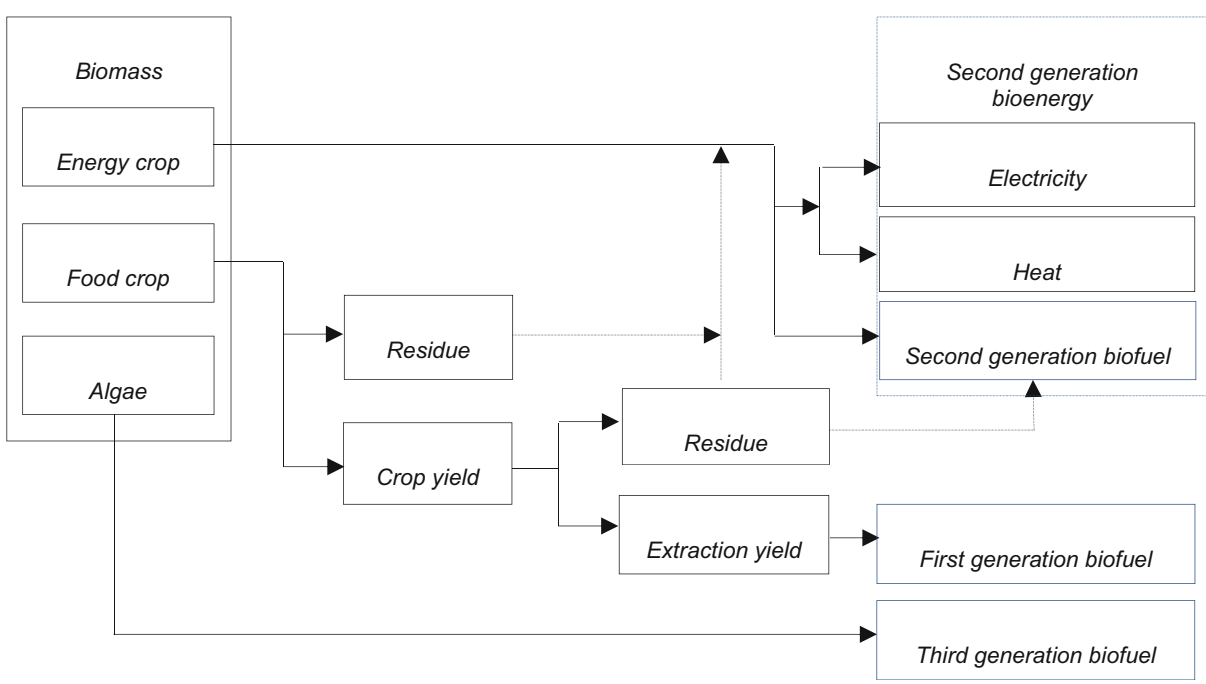

Fig. 2 Production chain bioenergy generating first, second and third generation biofuels and bioenergy (electricity and heat) (source: Gerbens-Leenes 2017) 
(2010). The most important crops that form the feedstock for bioethanol were included: sugar beet, sugar cane, potato, cassava, maize, barley, rye, paddy rice and wheat, as well as the main crops for biodiesel: palm oil, rapeseed and soybean. For second generation bioenergy, the study included residues from sugar beet, soybean, sugar cane, cassava, maize, wheat, paddy rice and rapeseed, as well as the energy crop miscanthus and the wood types pine and eucalyptus. Data on second generation bioenergy were derived from the study of Mathioudakis et al. (2017) into the WF of second generation bioenergy. This study also included the WF of firewood. The study derived data from Mekonnen et al. (2015). For third generation bioenergy, i.e., bioenergy from algae, the study derived data on WFs of algae energy from Gerbens-Leenes et al. (2014). Figure 2 shows the production chain of bioenergy generating first, second and third generation biofuels and bioenergy (electricity and heat).

The International Energy Agency developed three scenarios for energy use in 2040, the current policies scenario, the new policies scenario and the 450 scenario. The 450 scenario has the largest bioenergy use of 97 EJ per year (IEA 2016). To estimate the WF of future biomass use for bioenergy, the study calculated the global water consumption related to bioenergy use in 2040 based on the IEA scenario with the largest bioenergy share. For the estimation, the study combined bioenergy use according to the 450 scenario with average data on the WFs of first, second and third generation bioenergy. The total WF $\left(W F_{\text {total }}, \mathrm{m}^{3} / \mathrm{y}\right)$ is estimated as:

$$
W F_{\text {total }}=\sum_{s}(E \times W F[s])
$$

where $E$ is the bioenergy demand (GJ/y) of the 450 scenario, and $W F[s]$ the average WF per unit of bioenergy produced from bioenergy sources $\left(\mathrm{m}^{3} / \mathrm{GJ}\right)$. The study took data on WFs of first generation biofuels from Mekonnen and Hoekstra (2010), data on second generation from Mathioudakis et al. (2017) and data on WFs of third generation biofuels from Gerbens-Leenes et al. (2014). Next, the study compared the results with the global average WF between 1996 and 2005. The study derived data on the global average WF from Hoekstra and Mekonnen (2012).

\section{Results}

Fig. 3 shows global average water footprints (WFs) of first generation biofuels produced using different crops, i.e., sugar beet, sugar cane, potato, cassava, maize, barley, rye, paddy rice and wheat for bioethanol (in $\mathrm{m}^{3}$ per GJ bioethanol) and palm oil, rapeseed and soybean for biodiesel (in $\mathrm{m}^{3}$ per GJ biodiesel). The green WF, i.e., water from precipitation, dominates all WFs. Bioethanol from sugar cane, paddy rice and wheat has relatively large blue WFs, i.e., water from irrigation. Ethanol from potato and biodiesel from rapeseed has relatively large grey WFs. In general, the WFs of biodiesel are larger than the WFs of bioethanol. Figure 3 shows that for bioethanol, total WFs range between 50 and $180 \mathrm{~m}^{3}$ per GJ, and for biodiesel, total WFs range between 150 and $350 \mathrm{~m}^{3}$ per GJ.

Fig. 4 shows the WF of second generation biofuels from residues in $\mathrm{m}^{3}$ per GJ (bioethanol (E) and biodiesel (B)). Similar to the results of the first generation biofuels, the green WF dominates the WFs. Ethanol from sugar beet shows the smallest total WF, ethanol from rapeseed has the largest total WF. When the green, blue and grey WFs shown in Fig. 4 are 


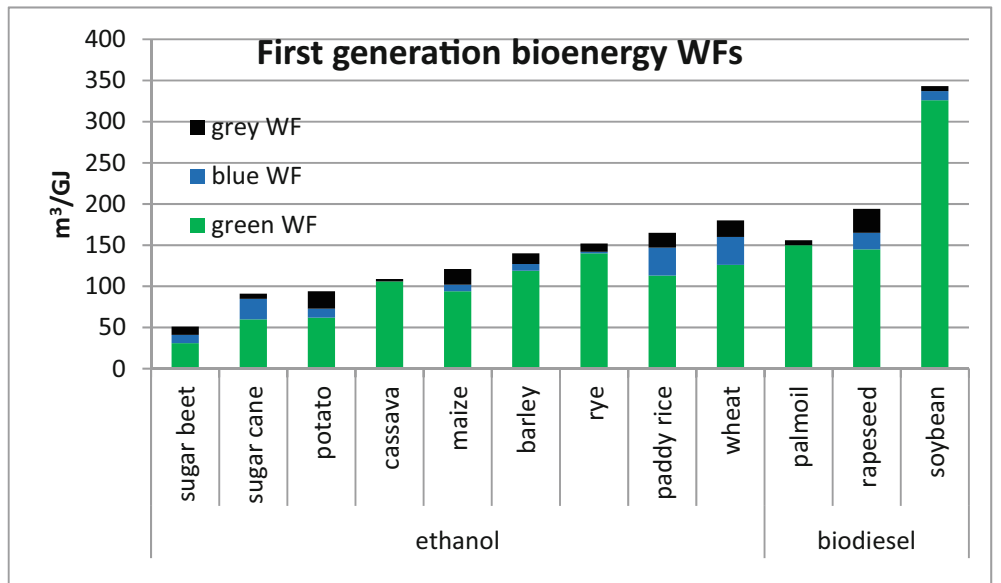

Fig. 3 Global average water footprint of first generation biofuel in $\mathrm{m}^{3}$ per GJ ethanol or per GJ biodiesel

compared to the WFs shown in Fig. 3, the WFs for second generation biofuel from residues are much smaller than WFs of first generation biofuels. The total average WF of bioethanol and biodiesel from sugar beet residue, for example, is 7 times smaller than bioethanol from sugar beet using fermentation of sugar.

Fig. 5 shows the WF of second generation biofuel, bioethanol, biodiesel and heat, from the energy crops miscanthus, eucalyptus, pine and firewood $\left(\mathrm{m}^{3}\right.$ per GJ). These energy crops are not irrigated and it is assumed that no fertilizer is applied. Therefore, biofuels generated from energy crops only have a green WF, and no blue or grey WF. Figure 5 shows that especially the WF of bioethanol or biodiesel from pine is large, almost $500 \mathrm{~m}^{3}$ per GJ for ethanol and $200 \mathrm{~m}^{3}$ per GJ for biodiesel. The green WF of heat from firewood is relatively small, between 19 and $100 \mathrm{~m}^{3}$ per GJ, with an average value of $60 \mathrm{~m}^{3}$ per GJ.

Fig. 6 gives an overview of the average green, blue and grey WFs of biofuels from agricultural residues, algae, food crops and energy crops shown in Figs. 3-5. The green WF dominates the WFs of first and second generation biofuels produced from food crops and

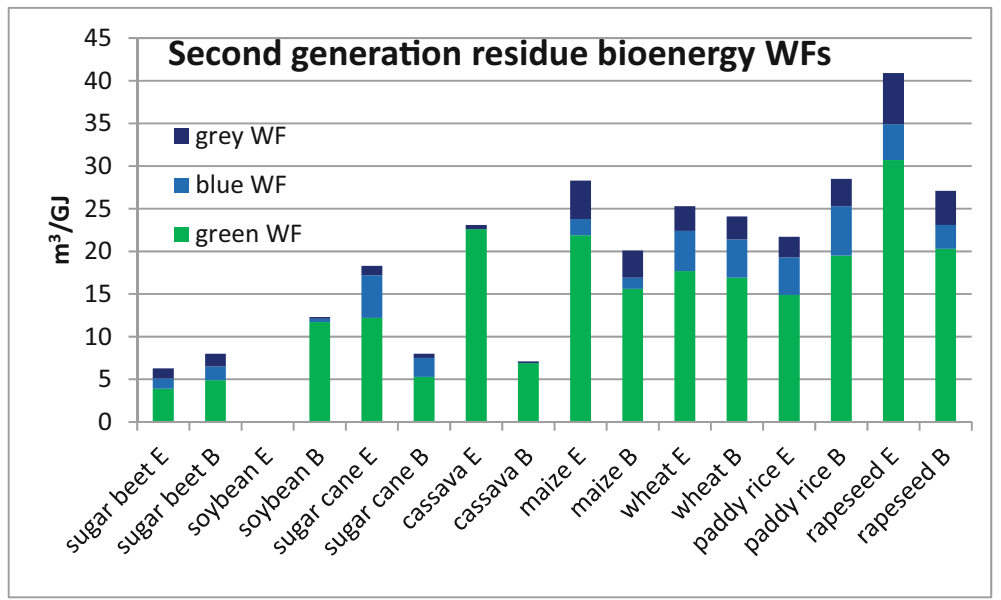

Fig. 4 Water footprint of second generation biofuel from residues in $\mathrm{m}^{3}$ per $\mathrm{GJ}$ ( $\mathrm{E}=$ ethanol; $\mathrm{B}=$ biodiesel) 


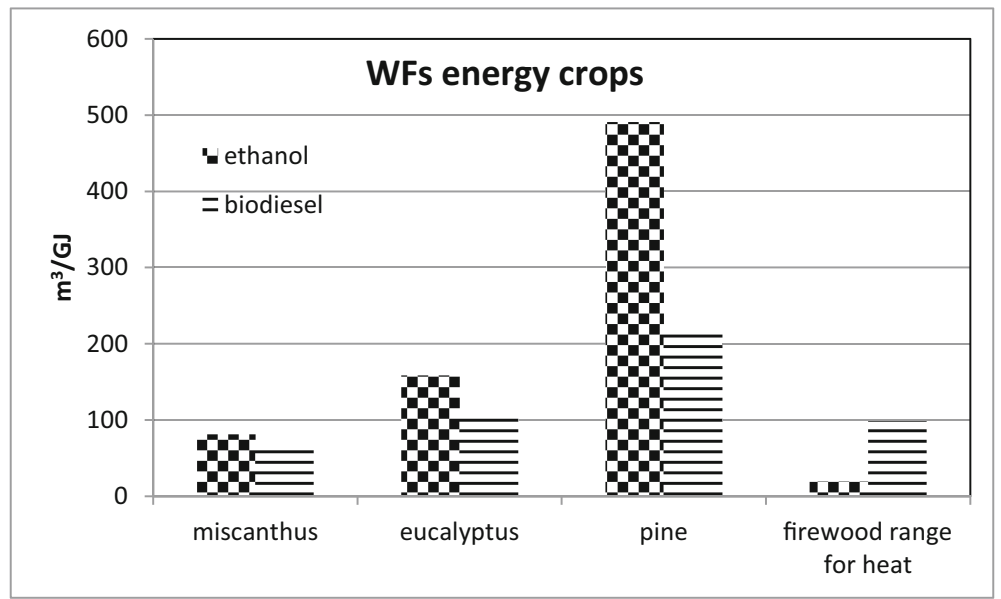

Fig. 5 Water footprint of second generation biofuel from energy crops in $\mathrm{m}^{3}$ per GJ

agricultural residues, while the blue and grey WFs are relatively small. The second generation biofuels from energy crops only have a green WF, while third generation biofuels from algae only have a blue WF and no green and grey WF. Figure 6 shows that the WFs of biofuels from residues are the smallest. The green WF of biofuel from energy crops is much larger than green WFs of the other biofuels. For biofuels from algae, the blue WF is the largest.

Fig. 7 shows an estimate of the global green, blue and grey WFs of bioenergy using different feedstocks, i.e., first generation food crops, second generation residues, second generation energy crops and third generation feedstock from algae, when the IEA New Policies Scenario for 2040 would be implemented. Figure 7 also shows the global average WF for the period 1996-2005 that includes total WFs for agricultural, industrial and domestic uses. Between 1996 and 2005, the global average WF was $9087 \mathrm{Gm}^{3}$ per year, of which $74 \%$ was green, $11 \%$ blue and $15 \%$ grey. $92 \%$ of this WF was related to agriculture. Crops require $7400 \mathrm{Gm}^{3}$ per year and pasture $900 \mathrm{Gm}^{3}$ per year (Hoekstra and Mekonnen 2012). Part of the

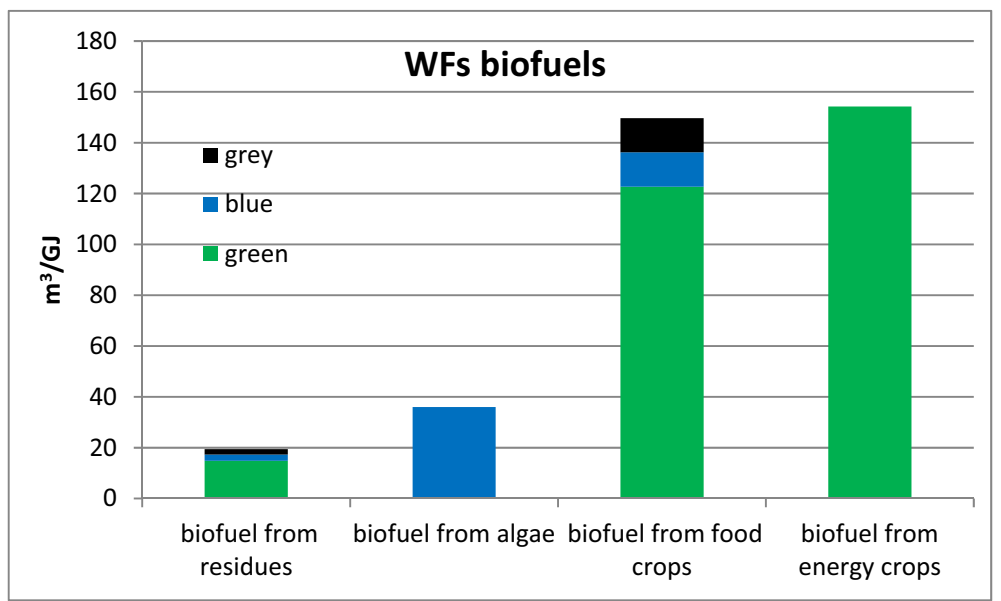

Fig. 6 Overview of average water footprints of first, second and third generation biofuel 


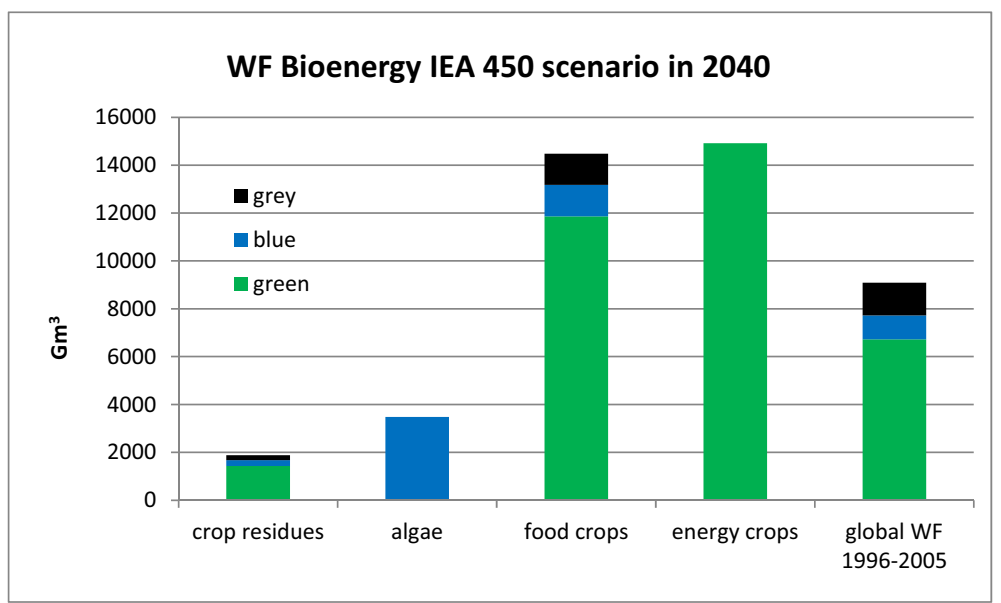

Fig. 7 Global water footprints using first generation bioenergy, second generation bioenergy from residues, second generation energy crops and third generation bioenergy in the IEA 450 scenario for 2040 and the average global water footprint in the period 1996-2005

crops is applied for energy purposes, for example, sugar cane in Brazil is partly used as a feedstock for ethanol. The figure also shows that if food or energy crops are applied for bioenergy, the WF for bioenergy in 2040 will exceed the global average WF for the period 1996-2005. If algae are applied as a feedstock for bioenergy, this might put large pressure on blue water resources. In that case, the blue WF is 3.5 times larger than the global average blue WF for the period 1996-2005.

In many regions of the world, water was already a scarce resource between 1996 and 2005. With the introduction of bioenergy in the IEA 450 scenario, the WF of bioenergy will exceed the global average WF from the end of the 20th and the beginning of the twenty-first century. When energy crops are applied, the green WF will exceed the average global green WF. For the third generation bioenergy, especially the blue WF might be problematic. The only option would be to use residues for bioenergy.

\section{Discussion}

- This study aimed to present an overview of average water footprints (WFs) of first, second and third generation bioenergy per unit of energy and to show the consequences of the global application of these types of bioenergy on freshwater resources for 2040. A simple average may hide the large WF variation within the different generation biofuels, but the differences among the first, second and third generation feedstocks are so large that the results give insight into the choice of a specific type of feedstock on freshwater consumption. It is emphasized, though, that the results are based on average numbers from earlier studies and that only one scenario with a large bioenergy use is applied. Therefore, the results should not be interpreted at face value, but as tools that give insight in the system and that provide information on the large differences among the feedstocks for bioenergy.

- For the comparison of green, blue and grey bioenergy WFs, the study derived data on WFs of bioenergy from existing studies. When more detailed data become available, the WFs 
may also change. Although uncertainty exists, the use of these data for the analysis of the IEA 450 scenario for 2040 with a large bioenergy use of 97 GJ shows the direction of the changes in WFs that can be expected if bioenergy is applied at a large scale. The study also shows that there are large differences among the energy feedstocks. The WFs of first generation feedstocks are much larger than WFs of second generation feedstocks from residues. Moreover, this WF contains not only a green component, but also a blue WF component related to irrigation and a grey one related to pollution. The WFs of second generation energy crops, like wood or miscanthus, are relatively large. However, they only contain the green component. The data for the third generation feedstocks, algae, have been based on a limited number of studies. Although other research might show more sustainable options to produce algae, the WF of algae feedstock is based on the application of blue water that has a larger impact on water scarcity than green water.

- The study applied the IEA 450 scenario with a relatively large bioenergy share (bioenergy use 97 EJ). The other two IEA scenarios, the current policies scenario (bioenergy use 77 EJ) and the new policies scenario (bioenergy use 79 EJ) will have smaller total WFs. A freshwater constraint for bioenergy production may make the current policies scenario and the new policies scenario more realistic than the IEA 450 scenario. The paper shows that a large contribution of modern bioenergy to the energy mix in 2040 based on food or energy crops exceeds the present global water footprint. If algae are applied as a feedstock, the present blue WF is exceeded. Only the application of crop residues is favorable in terms of water footprints. The large WFs of algae feedstocks (blue WF) or energy crops (green WFs) or the competition between crops for food and crops for energy might cause feedback mechanisms, decreasing bioenergy production. Future energy mixes might also change due to factors like shale gas development, larger implementation of wind or solar energy, changes in population characteristics or differences between reality in 2040 and the scenario outcomes.

- The results indicate that the IEA 450 scenario, in which modern bioenergy is supplied by crop residues, has the smallest WFs. However, nowadays residues are, among other things, applied for animal feed or to improve agricultural soil health. The organic matter concentration of a soil depends on the balance between input and output of organic matter. Input is applied in the form of crop residues, manure or compost; output in the form of yields, or losses of organic matter by oxidation. The soil organic matter concentration develops over a long period of time (Franzluebbers 2015). Using residues for energy purposes, therefore, might harm soil organic matter contents, and thus soil quality and agricultural outputs. Second generation feedstocks from energy crops do not have these drawbacks (Franzluebbers 2015).

- The study took the WFs of the residues from Mathioudakis et al. (2017) who calculated WFs of residues based on data on WFs of crops from Mekonnen and Hoekstra (2010) and reallocated WFs over the crop yield and the crop residue. This means that the total WF for agriculture does not increase, if total production remains the same. From this point of view, the scenario using residues is possible from a water perspective. However, the scenario depends on the availability of residues and the possibility to convert them into bioenergy. Monforti et al. (2013) have shown the enormous amounts of residues from agricultural crops available for energy purposes, but there are still technical challenges for their conversion into bioenergy. Moreover, it is uncertain whether all these residues are available for energy purposes. 


\section{Conclusions}

This study gives an overview of average water footprints (WFs) of first, second and third generation bioenergy per unit of energy, and shows the consequences of the global application of these types of bioenergy on water resources for 2040. The results provide information on the large differences among the WFs of the different feedstocks for bioenergy, and the consequences if applied in future energy mixes. This study gives an overview of the average green, blue and grey WFs of first, second and third generation bioenergy based on existing data from literature. It shows that residues are the most favourable bioenergy feedstocks in terms of water use. The total WF does not increase when residues are applied for energy purposes, because WFs are reallocated over the crop and the residue part. However, it is not certain whether these residues are available for bioenergy, because at present residues are also applied for animal feed or to improve the organic matter content in agricultural soils. When crops are grown specifically for energy, food crops or energy crops, the WFs are large. Food crops have a green, blue and grey WF, while WFs of energy crops, such as miscanthus, are dominated by a green WF. If modern bioenergy is applied on a large scale in future energy mixes, as proposed in the 450 IEA scenario for 2040, WFs will go up and the WF of bioenergy will even exceed the present global WF that includes water consumption in agriculture, industry and domestic services. In many river basins, water scarcity is happening already. The rising production of food crops for bioenergy purposes probably increases water scarcity. Bioenergy crops to supply bioenergy have a large green water footprint. A scenario based on energy crops as a feedstock also exceeds the present global green WF. For the third generation feedstock, algae, the blue WF exceeds the present blue WF. Using energy crops or algae for large-scale energy supply might not be realistic from a water perspective. Crop residue use for energy does not increase the WF, because all water was already allocated to the crops and the assessment has been based on a WF reallocation. More research is needed to assess whether crop residues are available on a large scale to be converted into energy feedstocks.

Acknowledgements An initial shorter version of the paper has been presented at the 10th World Congress of the European Water Resources Association (EWRA2017) "Panta Rhei", Athens, Greece, 5-9 July, 2017 (http://ewra2017.ewra.net).

Abbreviations $E J$, exajoule; $G J$ gigajoule; $I E A$ international energy agency; $W F$ water foortprint

Open Access This article is distributed under the terms of the Creative Commons Attribution 4.0 International License (http://creativecommons.org/licenses/by/4.0/), which permits unrestricted use, distribution, and reproduction in any medium, provided you give appropriate credit to the original author(s) and the source, provide a link to the Creative Commons license, and indicate if changes were made.

\section{References}

Abuelnuor AAA, Wahid MA, Hosseini SE, Saat A, Saqr KM, Sait HH, Osman M (2014) Characteristics of biomass in flameless combustion: a review. Renew Sust Energ Rev 33:363-370. https://doi.org/10.1016/j. rser.2014.01.079

Basu P (2013) Biomass Gasification, Pyrolysis and Torrefaction: Practical Design and Theory. Elsevier Science, San Diego

Carpenter DL, Bai RL, Davis RE, Dutta A, Feik CJ, Gaston KR, Jablonski W, Phillips SD, Nimlos MR (2010) Pilot-scale gasification of corn Stover, switchgrass, wheat straw, and wood: 1. Parametric study and comparison with literature. Ind Eng Chem Res 49:1859-1871 
Chen WH (2015) Nonoxidative torrefaction. In: Pandey A, Negi S, Binod P, Larroche C (eds) Pretreatment of Biomass: Processes and Technologies. Elsevier, Amsterdam, p 176

Cleveland CJ, Morris CG (2005). Dictionary of Energy. Elsevier Science, ltd, Amsterdam

Davies EGR, Kyle P, Edmonds JA (2013) An integrated assessment of global and regional water demands for electricity generation to 2095. Adv Water Resour 52:296-313

De Jong W, Van Ommen JR (2014) Introduction: socioeconomic aspects of biomass conversion. In: De Jong W, Van Ommen JR (eds) Biomass as a Sustainable Energy Source for the Future: Fundamentals of Conversion Processes. John Wiley \& Sons, Inc., Hoboken

El Bassam N (2010) Handbook of Bioenergy Crops: a Complete Reference to Species, Development and Applications. Earthscan, Washington

FAO (2006) Introducing the International Bio-energy Platform. Rome, Italy

Ekșioğlu SD, Li S, Zhang S, Sokhansanj S, Petrolia D (2010) Analyzing impact of intermodal facilities on design and management of biofuel supply chain. Transp Res Rec J Transp Res Board 2191:144-151

Fischer H, Hizsnyik E, Prieler S, Shah M, Van Velthuizen H (2009) Biofuels and Food Security. International Institute for Applied Systems Analysis, Laxenburg

Franzluebbers AJ (2015) Farming strategies to fuel bioenergy demands and facilitate essential soil services. Geoderma 259-260:251-258

Fritsche UR, Iriartre L (2014) Sustainability criteria and indicators for the bio-based economy in Europe: state of discussion and way forward. Energies 7:6825-6836. https://doi.org/10.3390/en7116825

Gallagher PW, Dikeman M, Fritz J, Wailes EJ, Gauthier WM, Shapouri H (2003) Biomass from Crop Residues: Cost and Supply Estimates. United States Department of Agriculture, Economic Research Service, Ames

Gerbens-Leenes PW (2017) Bioenergy water footprints, comparing first, second and third generation feedstocks for bioenergy supply in 2040. European Water 59:373-380

Gerbens-Leenes PW, Hoekstra AY, Van der Meer TH (2009) The water footprint of bioenergy. Proc Natl Acad Sci 106:10219-10223

Gerbens-Leenes PW, Xu L, De Vries GJ, Hoekstra AY (2014) The blue water footprint and land use of biofuels from algae. Water Resour Res 50:8549-8563

Hansen MW (2006) Thermal Gasification of Biomass. IEA Bioenergy Agreement Task 33. Proceedings workshop 2: Gas cleaning \& gas engines for small-scale biomass gasification applications, Copenhagen

Hejazi M, Edmonds J, Clarke L, Kyle P, Davies E, Chaturvedi V, Wise M, Patel P, Eom J, Calvin K, Moss R, Kim S (2014) Long-term global water projections using six socioeconomic scenarios in an integrated assessment modeling framework. Techno Forecast Soc Change 81:205-226

Higman C, Van der Burgt M (2011) Gasification. Gulf Professional Publishing, Houston, p 456

IEA (2007) IEA bioenergy 27th update. Biomass Bioenergy 31:VII-XVIII. https://doi.org/10.1016/S09619534 (07)00047-5

IEA (2008) Assessing measures of energy efficiency performance and their application in industry. In support of the G8 plan for action. IEA Information Paper, Paris

IEA (2012) World energy outlook 2012. International Energy Agency, Paris

IEA (2016) World energy outlook (2016). International Energy Agency, Paris

Hoekstra AY, Chapagain AK, Aldaya MM, Mekonnen MM (2011) The water footprint assessment manual: setting the global standard. Earthscan, London

Hoekstra AY, Mekonnen MM (2012) The water footprint of humanity. Proc Natl Acad Sci 109(9):3232-3237

Karlen D, Wollenhaupt NC, Erbach D, Berry E, Swan J, Eash N, Jordahl J (1994) Crop residue effects on soil quality following 10-years of no-till corn. Soil Tillage Res 31:149-167

Koopmans A, Koppejan J (1997) Agricultural and forest residues-generation, utilization and availability. Pap Present Reg Consult Mod Appl Biomass Energy 6:10

Kumar K, Goh K (1999) Crop residues and management practices: effects on soil quality, soil nitrogen dynamics, crop yield, and nitrogen recovery. Adv Agron 68:197-319

Mathioudakis V, Gerbens-Leenes PW, Van der Meer TH, Hoekstra AY (2017) The water footprint of second-generation bioenergy: a comparison of biomass feedstocks and conversion techniques. J Clean Prod 148:571-582

Mekonnen MM, Gerbens-Leenes PW, Hoekstra AY (2016) Future electricity: the challenge of reducing both carbon and water footprints. Sci Total Environ 569-570:1282-1288

Mekonnen MM, Hoekstra AY (2010) The green, blue and grey water footprint of crops and derived crop products. Value of Water Research Report Series No. 47, UNESCO-IHE, Delft, the Netherlands. http://www. waterfootprint.org/Reports/Report47-WaterFootprintCrops-Vol1.pdf

Mekonnen MM, Gerbens-Leenes PW, Hoekstra AY (2015) The consumptive water footprint of electricity and heat: a global assessment. Environ Sci Water Res Technol 1:285-297

Mbohwa C (2006) Modelling bagasse electricity generation: an application to the sugar industry in Zimbabwe. In: JAM T-W (ed) Proceedings of the International Conference on Advances in Engineering and Technology. Elsevier Science Ltd, Oxford, pp 354-367 
Monforti F, Bódis K, Scarlat N, Dallemand JF (2013) The possible contribution of agricultural crop residues to renewable energy targets in Europe: a spatially explicit study. Renew Sust Energ Rev 19:666-677

Mood SH, Hossein Golfeshan A, Tabatabaei M, Salehi Jouzani G, Najafi GH, Gholami M, Ardjmand M (2013) Lignocellulosic biomass to bioethanol, a comprehensive review with a focus on pretreatment. Renew Sust Energ Rev 27:77-93. https://doi.org/10.1016/j.rser.2013.06.033

Pekel JF, Cottam A, Gorelick N, Belward AS (2016) High-resolution mapping of global surface water and its long-term changes. Nature, Letter 540:418-422. https://doi.org/10.1038/nature20584

Repic B, Dakic D, Djurovic D, Eric A (2010) Development of a boiler for small straw bales combustion. In: Artie $\mathrm{Ng}$ (Ed), Paths to Sustainable Energy. InTech, pp 647-664. https://doi.org/10.5772/13215. Available from: https://www.intechopen.com/books/paths-to-sustainable-energy/development-of-a-boiler-for-smallstraw-bales-combustion

Sawatdeenarunat C, Surendra KC, Takara D, Oechsner H, Khanal SK (2015) Anaerobic digestion of lignocellulosic biomass: challenges and opportunities. Bioresour Technol 178:178-186. https://doi.org/10.1016/j. biortech.2014.09.103

Shiklomanov IA (2000) Appraisal and assessment of world water resources, Water International, 25(1):11-32. https://doi.org/10.1080/02508060008686794

Speidel DH, Ruedisili LC, Agnew AF (1988) Perspectives on Water: Uses and Abuses. Oxford University Press, New York

Stevens C, Brown RC (2011) Introduction to thermochemical processing of biomass into fuels, chemicals and power. In: Brown CR (Ed), Thermochemical Processing of Biomass: Conversion into Fuels, Chemicals and Power. John Wiley and Sons, Hoboken, pp 1-6 